\title{
Учебное пособие по международному
}

\section{трудовому праву.}

\section{Бекяшев Д.К. Международное трудовое} право: Учеб. пособие.

М.: ТК Велби, Изд-во «Проспект», -2008. -336 c.

\section{Моисеев E.Г.*}

Литература по международному праву пополнилась новым учебным пособием «Международное трудовое право», подготовленным кандидатом юридических наук, доцентом кафедры международного права МГИМО (Университета) МИД России Дамиром Камильевичем Бекяшевым.

Следует согласиться с автором, который в предисловии говорит о том, что международное трудовое право в России не изучено и не представлено в качестве составной части общего курса по международному праву. Ни в одном из более чем 40 изданных в России учебников по международному праву нет главы или раздела, который был бы посвящен международному трудовому праву. Между тем международное трудовое право и по своей значимости, и по массиву правовых норм, составляющих данную отрасль, претендует на ведущие роли в современной системе международного права.

Необходимо отметить, что рецензируемое издание - первое в России учебное пособие, в котором в систематизированном виде освещены проблемы международного трудового права как самостоятельной отрасли международного публичного права.

Пособие состоит из четырех глав, списка литературы и пяти приложений.

В первой главе (с. 5-22) изложены основы теории международного трудового права. Здесь говорится об истории возникновения и развития данной отрасли международного права, ее понятии, предмете, принципах и субъектах, источниках, а также контроле за соблюдением государствами конвенций Международной организации труда (МОТ).

\footnotetext{
* Моисеев Евгений Григорьевич - д.ю.н., профессор кафедры международного права Московской государственной юридической академии.
} 
В данной главе можно выделить раздел о принципах международного трудового права (с. 10-12). Среди принципов, которые сложились и действуют в данной отрасли на протяжении последних десятилетий, автор особо выделяет те, которые вытекают из норм и деятельности MOT. К ним он относит следующие принципы:

- принцип универсальности, означающий возможность вступления в МОТ любого государства, которое берет на себя предусмотренные ее Уставом обязательства;

- принцип трипартизма (трехсторонности), означающий, что в работе МОТ наряду с представителями государств-членов на равных с ними основаниях участвуют представители работодателей и работников;

- принцип контроля за соблюдением конвенций MOT, означающий, что в данной организации действует целый ряд контрольных механизмов, позволяющих ей оценивать степень выполнения положений конвенций государствами-членами после их ратификации.

Вторая глава (с. 23-41) посвящена Международной организации труда, ее правовому статусу, структуре, основным направлениям деятельности, а также сотрудничеству МОТ с другими международными организациями. Информация и суждения автора, содержащиеся в данной главе, дают ясное представление об этой авторитетной международной организации, которая имеет статус специализированного учреждения ООН.

Во второй главе можно выделить раздел об основных направлениях деятельности MOT (с. 33-39). Такими направлениями являются: вопросы достойного труда и создания рабочих мест; гендерного равенства; повышения профессионального уровня; безопасности труда; укрепления трипартизма и социального диалога; содействия нормам, основополагающим принципам и правам в сфере труда и их реализации и ряд других. Содержание каждого из этих направлений раскрыто в учебном пособии.

В третьей главе (с. 42-71) речь идет о международной защите трудовых прав человека, международно-правовом регулировании труда отдельных категорий работников, правовом регулировании труда и статуса трудящихся-мигрантов на международном уровне, об участии Российской Федерации в международном регулировании труда.

В этой главе выделим раздел, посвященный международно-правовому регулированию труда отдельных категорий работников (с. 49-56). 
Автор более детально говорит об особенностях международно-правового регулирования труда следующих категорий работников: женщин; детей и подростков; трудящихся-мигрантов; коренного населения и населения, ведущего племенной образ жизни; моряков, рыбаков, докеров; работников сельского хозяйства; младшего медицинского персонала; работников гостиниц и ресторанов; надомников.

Кроме того, обращает на себя внимание раздел третьей главы об участии России в международном регулировании труда (с. 68-71). Наша страна тесно сотрудничает с МОТ: работает над проектами конвенций и рекомендаций, принимает и ратифицирует конвенции, разрабатывает программы сотрудничества России и MOT, приглашает экспертов и аналитиков организации и т.д.

Наконец, в четвертой главе (с. 72-83) говорится о правовом регулировании труда сотрудников международных организаций, Административном трибунале $\mathrm{OOH}$, а также об Административном трибунале МОТ. Эта часть пособия представляет собой безусловный интерес, поскольку в отечественной учебной и доктринальной литературе статус и деятельность данных трибуналов практически не рассмотрены.

Привлекает внимание список литературы по международному трудовому праву, который состоит из трех частей. В первой части «Монографии, учебники, сборники» представлены 33 издания на русском языке и 23 издания на иностранных языках. Во второй части списка названы десять наиболее важных докладов МОТ за последние двадцать лет. В третьей части содержатся названия 21 статьи на русском языке и 11 - на английском.

Нельзя не сказать о пяти приложениях (с. 89-334) рецензируемого пособия. В первом приложении изложен Устав МОТ; во втором - перечень ее конвенций; в третьем представлены тексты основных конвенций организации; в четвертом - некоторые декларации MOT; наконец, в пятом приложении помещен перечень конвенций МOT, ратифицированных Российской Федерацией.

В целом рецензируемый труд Дамира Бекяшева представляется весьма интересным, нужным, подготовленным на высоком профессиональном уровне. Привлекает внимание язык учебного пособия - профессиональный язык состоявшегося ученого, одновременно простой и ясный для понимания.

В рецензии не обойтись без замечаний и пожеланий. Представляется, что в данной работе следовало больше внимания уделить 
ее методической стороне. Например, можно было бы снабдить пособие таблицами и схемами, которые можно было бы применить при чтении лекционного курса и проведении семинарских и практических занятий со студентами. Не лишними были бы тесты по международному трудовому праву. Можно было бы дополнить каждую главу вопросами и иными заданиями для студентов, а в конце сформулировать темы для курсовых и дипломных работ по данному курсу.

Что касается пожеланий автору, то заметим, что ему под силу подготовить солидную монографию по одному из институтов международного публичного права. Напомним, что в 2004 году Д.К. Бекяшев выпустил монографию, посвященную труду моряков и рыбаков. Однако прошло четыре года, принято несколько новых документов, касающихся международно-правового регулирования различных категорий работников, чей труд связан с Мировым океаном. На наш взгляд, следовало бы их проанализировать и представить анализ и обобщение в специальном монографическом труде. Кроме того, есть настоятельная необходимость написать специальную работу, посвященную правовому статусу трудящихся-мигрантов.

В заключение еще раз хочется поблагодарить молодого ученого и преподавателя Дамира Бекяшева за рецензируемый труд, который является существенным вкладом в науку и практику международного права, и пожелать автору дальнейших творческих успехов.

\section{Review of a New Textbook on International Labour Law \\ D.K. Bekyashev International Labour Law: textbook. Moscow, TK Welby, Publishing house "Prospekt", 2008. 336 p.}

(Summary)

Evgeniy G. Moiseev*

In the international law literature there appeared a new book "International Labour Law" written by Damir K. Bekyashev, an associate professor

\footnotetext{
* Evgeniy G. Moiseev - Doctor of Laws, professor of the Chair of International Law of the Moscow State Law Academy.
} 
of the International Law Department in the Moscow State Institute of Foreign Affairs (University), Ph.D in Law. The book under review is the first book in Russia where the author covers in a systematic way key issues of international labour law as an autonomous branch of international public law. The book is comprised of four chapters, a bibliography, and five appendices. Chapter 1 contains the fundamentals of the international labour law theory. Chapter 2 is devoted to the International Labour Organization (ILO), its legal status, structure, general directions of its activity, as well as the ILO cooperation with other international organizations. In chapter 3 the author examines the issues of international protection of labour rights, international legal regulation of labour of separate categories of workers including migrant workers, the participation of the Russian Federation in this process. In chapter 4 the author analyzes legal regulation of labour of international organizations officials, the UN Administrative Tribunal, as well as the ILO Administrative Tribunal.

The book under review is quite interesting and necessary; it is prepared on a high professional level. The manner of delivering the material is that of a full-fledged scholar, simultaneously quite simple and easy for understanding.

However, one cannot do without a number of comments and wishes to be expressed. The author of the book should have paid more attention to the methodology adding tables and schemes, which could be used in lectures and seminars. Tests on international labour law would also have been advantageous for the book. The author could have placed questions and other assignments for students at the end of each chapter, and he could have formulated topics for course papers and diploma papers at the very end of the book. The reviewer wishes the author would prepare a sound monograph on one of the international labour law institutes. In 2004 Damir K. Bekyashev already had a monograph published on the labour of seafarers and fishermen. However, four years have passed since; lots of new documents have been adopted in the sphere of international legal regulation of labour of different categories of workers in the World Ocean. Besides, there exists an urgent need for a special work devoted to the labour of migrant workers. 